\title{
Distribution of lead-203 in human peripheral blood in vitro
}

\author{
C N ONG* AND W R LEE \\ From the Department of Occupational Health, University of Manchester, Manchester M13 9PT, UK
}

\begin{abstract}
In-vitro experiments using ${ }^{203} \mathrm{~Pb}$ were performed to identify the lead binding components in human peripheral blood. The distribution of lead in plasma, in the red cell membrane, and within the red cell was also investigated. Studies of the distribution of ${ }^{203} \mathrm{~Pb}$ in whole blood showed that at a lead concentration of $2.45 \mu \mathrm{mol} / 1(50 \mu \mathrm{g} / 100 \mathrm{ml})$ about $94 \%$ of lead had been incorporated by the erythrocytes and $6 \%$ remained in the plasma. After extraction of lipid by a methanol/ chloroform mixture, about $75 \%$ of the lead was found to be associated with the protein fraction. The lipid contained about $21 \%$ of the ${ }^{203} \mathrm{~Pb}$, the remainder being in the aqueous plasma. SDS polyacrylamide gel electrophoresis of blood plasma showed that almost $90 \%$ of the ${ }^{203} \mathrm{~Pb}$ was present in the albumin fraction; the remainder was likely to be associated with high molecular weight globulins. Several binding sites were identified on the erythrocyte membrane. The high molecular weight component, about $130000-230000$, was the most important ${ }^{203} \mathrm{~Pb}$ binding site. Chemical modification of membrane proteins suggested that the carboxyl groups are the major ligand responsible for most of the lead binding. SH groups of the membrane may have a minor role, but amino groups did not appear to affect the lead binding. The binding of lead to erythrocytes was not confined to membranes, over $80 \%$ of lead in blood penetrates into erythrocytes and binds to intracellular components. Gel chromatography of the haemolysate showed that over $90 \%$ of the ${ }^{203} \mathrm{~Pb}$ was attached to the haemoglobin molecule.
\end{abstract}

The mechanism by which lead transfers from the external to the internal environment is not fully understood, but it is generally agreed that this metal is transported by the peripheral blood. ${ }^{2}$

Numerous studies on the uptake and binding of lead with peripheral blood have not succeeded in showing clearly either the mechanism of interaction or the binding site. Mortensen and Kellog ${ }^{3}$ suggested that lead is bound to the red blood cell or to the plasma, and only a small amount is in a free ionised form. Clarkson and Kench ${ }^{4}$ showed that lead has a high affinity for the erythrocytes.

The precise lead binding site in the red cell, however, is still unknown. On the one hand, several investigators consider that the most likely sites of fixation are in the cell membrane. ${ }^{5}$ Reddi $^{6}$ proposed that there may be two components in the red cell

\footnotetext{
*Present address: Department of Social Medicine and Public Health, University of Singapore, Outram Hill, Singapore 3.
}

Received 11 December 1978

Accepted 18 May 1979 responsible for the lead uptake; one is protein and the other a non-protein, probably a phenolic compound. This hypothesis has been discounted by Clarkson and Kench, ${ }^{4}$ who suggested that lead exists in the blood as a peptised lead phosphate-sol, the groups of which are probably aggregated on the surface of the cell to form a larger particulate. On the other hand, recent studies by Barltrop and Smith ${ }^{7} 8$ using tracer ${ }^{203} \mathrm{~Pb}$ do not confirm that lead has an affinity to the red blood cell membrane. These authors separated the ${ }^{203} \mathrm{~Pb}$-containing fraction of RBC by sephadex gel filtration and ultracentrifugation. Lead was found attached to the intracellular constituents rather than the stromal membrane, and to a molecule similar in size to the haemoglobin polypeptide. White, ${ }^{9}$ however, and Selhi and White ${ }^{10}$ believe that the attachment takes place in the erythrocyte membrane, which results in alteration of membrane protein conformation.

The identification of specific lead binding sites in the blood is hindered by experimental difficulties such as the necessity to detect and to measure trace amounts of lead in microsamples of subcellular 
components and complex separation procedures. It was hoped, by using the tracer ${ }^{203} \mathrm{~Pb}$ to $(a)$ study the distribution of lead in peripheral blood, and $(b)$ identify the lead binding site(s) in various blood constituents.

\section{Materials and methods}

\section{CHEMICALS AND RADIOCHEMICALS}

Tris-(hydroxylmethyl)-aminomethane was obtained from Hopkins and William (Searle) Co. Molecular weight markers for PAGE and gel filtration calibration were purchased from BDH Ltd; acrylamide and $\mathrm{NN}^{\prime}$-methylene-bis-acrylamide from Bio-Rad Lab. Sephadex G-75 was purchased from Pharmacia (UK) Ltd; TEMED, DTT, and ammoniumpersulphate were reagent grade from Sigma (London). Protein standard, bovine serum albumin was obtained from BDH Ltd.

Commercially available enzymes and chemicals to identify the lead binding groups were obtained from Sigma (London).

${ }^{203} \mathrm{~Pb}$ was prepared in a cyclotron (MRC unit, London) by bombardment of a thallium target and was carrier free.

Blood was obtained from volunteers by venepuncture, with heparin as anticoagulant.

DETERMINATION OF RADIOACTIVITY AND OF LEAD IN BLOOD

Determinations of radioactivity and of lead in blood were carried out by the methods described by Ong and Lee in the companion paper. ${ }^{11}$

\section{IDENTIFICATION OF LEAD IN PLASMA}

The approach to plasma protein electrophoresis was based on that described by Tombs and Akroyd. ${ }^{12}$ Electrophoresis was carried out with a current of $5 \mathrm{~mA}$ along each tube and at a voltage gradient of about $7 \mathrm{~V} / \mathrm{cm}$ until the marking dye reached a preset mark about $0.5 \mathrm{~cm}$ from the end of the gel.

The gel was stained overnight with $0.25 \%$ Coomassie blue in methanol, acetic acid, and water (50:10:40 by volume). Destaining was carried out with methanol, acetic acid, and water as above for 48 hours, with three changes of wash solution. After destaining, the gels were scanned with a Beckman model 26 double beam UV spectrophotometer with access to a transverse scanner.

PREPARATION OF ERYTHROCYTE MEMBRANES Erythrocyte membranes were prepared by the methods described in the companion paper. ${ }^{11}$
ENZYMIC MODIFICATION OF ERYTHROCYTE MEMBRANE

Membranes containing ${ }^{203} \mathrm{~Pb}$ were incubated with trypsin, phospholipase- $\mathrm{C}$, and neuraminidase in $10 \mathrm{mM}$ Tris- $\mathrm{HCl}$ buffer ( $\mathrm{pH} \mathrm{7.0)}$ according to the methods of Duffy and Schwarz. ${ }^{13}$

The mixture contained $\mathbf{0 \cdot 1} \mathrm{mg}$ of enzyme protein per $\mathrm{mg}$ of membrane protein in a total volume of 1 $\mathrm{ml}$. The reaction was terminated by the addition of

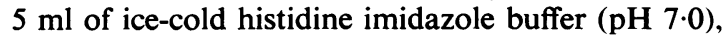
and the membranes were centrifuged at $6000 \mathrm{~g}$ for 20 minutes at $4^{\circ} \mathrm{C}$. The membranes were then washed twice more with this buffer, and the radioactivity was measured by gammaspectrometry. The soluble fraction was subjected to overnight dialysis in a high salt content, and the radioactivity of free lead was determined.

\section{CHEMICAL MODIFICATION OF ERYTHROCYTE MEMBRANES}

Chemical reagents were used to identify the principal lead binding molecule(s) in the membrane by the methods described by Ong and Lee. ${ }^{11}$

MOLECULAR GROUP RESPONSIBLE FOR LEAD BINDING IN THE ERYTHROCYTE MEMBRANE

The proteins of the human erythrocyte membrane were separated by polyacrylamide gel electrophoresis as described by Fairbanks et al $^{14}$ in $1 \%$ sodium dodecyl sulphate (SDS).

Solubilisation of red cell membrane before electrophoresis was achieved by adding $0.5 \mathrm{ml}$ of a solution containing $3 \%$ SDS, $0 \cdot 1 \%$ mercaptoethanol, $0 \cdot 1 \mathrm{M}$ Tris- $\mathrm{HCl}$ at $\mathrm{pH} 7.6$ to $0.5 \mathrm{ml}$ of the membrane suspension, and the solution was incubated at $37^{\circ} \mathrm{C}$ for 30 minutes. Suspensions containing 50-70 $\mu \mathrm{g}$ of the membrane proteins with $2 \% \mathrm{SDS}, 6 \%$ sucrose, and Bromophenol blue were applied for electrophoresis. They were introduced by gravity flow through a $20 \mu \mathrm{l}$ Dummond microcap and discharged gently on to the top of the gel.

Electrophoresis was performed with the current at $8 \mathrm{~mA}$ along each tube. The running time was about 90 minutes. The electrophoresis process was carried out in an apparatus that could run six columns simultaneously. The position of the tracking dye was marked in each gel by pricking it with a fine syringe needle dipped with Indian ink. Duplicate gels, unstained, were sliced and applied for radioactivity screening.

Commercially available proteins of known molecular weight were used as markers for molecular weight calibration of the gel. The protein standards used were as follows: bovine serum albumin, human gammaglobulin, ovalbumin, IgG, cytochrome-C, and pepsin. 
EXTRACTION OF PROTEIN AND LIPID

Lipids and proteins were extracted from whole blood, plasma, and erythrocyte according to the method described by Ong and Lee. ${ }^{11}$

IDENTIFICATION OF HAEMOGLOBIN ON G-75

Samples of haemolysate were separated by gel filtration chromatography on Sephadex G-75. The basic procedure was similar to that of Takeda et al. ${ }^{15}$

After incubation with $10 \mu \mathrm{Ci}$ of ${ }^{203} \mathrm{~Pb}$, the erythrocytes were washed twice with saline buffer and lysed with six volumes of double distilled water. The stroma was removed by centrifugation at $30000 \mathrm{~g}$, and the supernatant was then converted to cyanhaemoglobin by adding $50 \mu \mathrm{mol}$ of sodium cyanide. The lysate was then dialysed against 500 volumes of $0.1 \mathrm{M}$ Tris- $\mathrm{HCl}$ buffer, $\mathrm{pH} 8 \cdot 1$, at $5^{\circ} \mathrm{C}$, containing $50 \mu \mathrm{mol}$ of $\mathrm{CN}^{-}$, with two changes overnight. The Sephadex column $(40 \times 18 \mathrm{~cm})$, which had been calibrated with globulin, albumin, and pepsin, was equilibrated with the same buffer overnight. Thirty $\mathrm{mg}$ of the lysate were layered on to the column and eluted with $0.1 \mathrm{M}$ Tris- $\mathrm{HCl}$ buffer.

The haemoglobin fraction was scanned at 495 or $539 \mathrm{~nm}$ or both. Fractions absorbing at $280 \mathrm{~nm}$ for protein were also recorded. All fractions were determined for radioactivity.

\section{Results}

DISTRIBUTION OF ${ }^{203} \mathrm{~Pb}$ IN BLOOD

The percentage distribution of ${ }^{203} \mathrm{~Pb}$ in plasma,

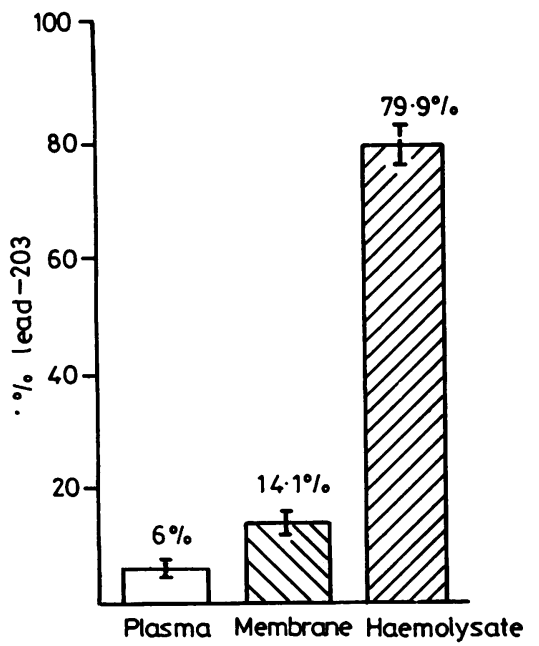

Fig 1 Percentage distribution of ${ }^{203} \mathrm{~Pb}$ distribution in peripheral blood.
Table 1 Distribution of bound ${ }^{203} \mathrm{~Pb}$ in whole blood

\begin{tabular}{|c|c|c|}
\hline Fraction & $\mu m o l / l \pm S E M^{*}$ & $\begin{array}{l}\% \text { of lead in the } \\
\text { fraction* }\end{array}$ \\
\hline \multicolumn{3}{|c|}{ Incubated with $2.45 \mu \mathrm{mol} / \mathrm{l}$ of ${ }^{203} \mathrm{PbCl}_{2}$} \\
\hline Protein & $1.63 \pm 0.07$ & $74 \cdot 4 \pm 4 \cdot 15$ \\
\hline $\begin{array}{l}\text { Lipid } \\
\text { Aqueous }\end{array}$ & $0.48 \pm 0.01$ & $21.9 \pm 1.09$ \\
\hline \multicolumn{3}{|c|}{ Incubated with $4.85 \mu \mathrm{mol} / \mathrm{l}$ of ${ }^{203} \mathrm{PbCl}_{2}$} \\
\hline Protein & $3.46 \pm 0.12$ & $72.8 \pm 3.25$ \\
\hline Lipid & $1 \cdot 12 \pm 0.02$ & $23 \cdot 6 \pm 1 \cdot 20$ \\
\hline Aqueous & $0.17 \pm 0.01$ & $3.6 \pm 0.05$ \\
\hline
\end{tabular}

*Means of three experiments each in duplicate.

haemolysate, and stromal membrane is shown in fig 1 . A high proportion of lead $(80 \%)$ had penetrated the erythrocyte membrane to bind with the non-stromal fraction, whereas only a small amount $(14 \%)$ of the ${ }^{203} \mathrm{~Pb}$ was attached to the membrane fraction. Blood plasma contained an even smaller amount of the ${ }^{203} \mathrm{~Pb}$ (about $6 \%$ ).

DISTRIBUTION OF ${ }^{203} \mathrm{~Pb}$ IN WHOLE BLOOD

AFTER EXTRACTION OF LIPID

Table 1 shows the results of ${ }^{203} \mathrm{~Pb}$ distribution at molecular level. The protein fraction contained most $(74 \%)$ of the total lead present. About $22 \%$ of the ${ }^{203} \mathrm{~Pb}$ was found in the organic (lipid-containing) phase and about 3\% was found unassociated, probably in free ionic form.

The experiment was repeated with $4.85 \mu \mathrm{mol} / 1$ of ${ }^{203} \mathrm{~Pb}$ in the incorporating phase. The results (table 1) indicate that an increase of the lead concentration in the incorporating phase did not appear to alter the binding percentage significantly.

MOLECULAR GROUPS RESPONSIBLE FOR ${ }^{203} \mathrm{~Pb}$ BINDING IN THE PLASMA

A preliminary investigation was undertaken to detect the primary distribution of lead in the plasma using the methods of Turner and Hulme. ${ }^{16}$ The plasma was arbitrarily classified into albumin and the globulins. The results of three experiments, each in duplicate on the ${ }^{203} \mathrm{~Pb}$ distribution in those two protein subgroups, are summarised in table 2 . A large proportion $(88.2 \%)$ of the labelled material was in the albumin.

The finding that only $12 \%$ of ${ }^{203} \mathrm{~Pb}$ was attached to the globulins is interesting, as it is generally assumed

Table 2 Distribution of lead in the plasma

\begin{tabular}{lll}
\hline Fraction & $\begin{array}{l}\text { nmol/g of protein } \\
\text { (Mean } \pm \text { SEM) }\end{array}$ & $\begin{array}{l}\text { \% of lead in the } \\
\text { fraction }\end{array}$ \\
\hline Albumin & $157.42 \pm 25.2$ & 88.2 \\
Globulin & $20.38 \pm 1.4$ & 11.8
\end{tabular}

Recovery of radioactivity was $87 \%$ and $82 \%$. respectively. 


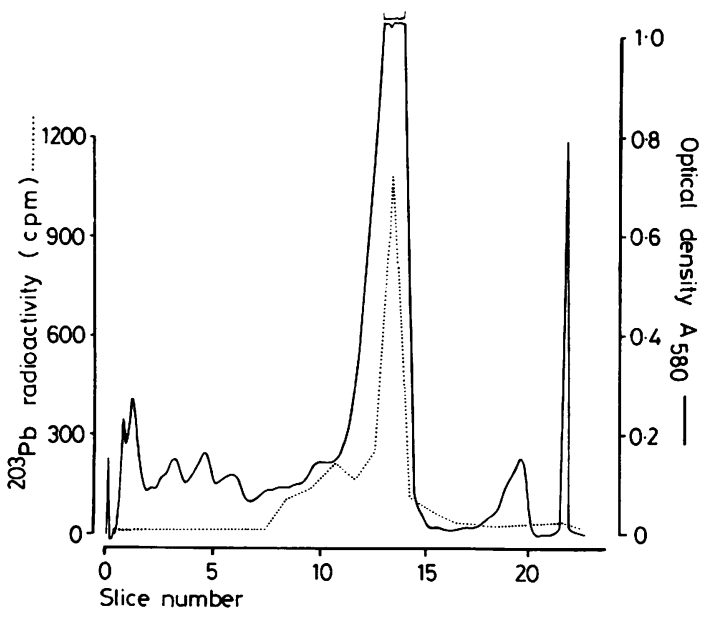

Fig 2 Densitometric scan of plasma polypeptide after electrophoresis.

that lead does not appear to be associated with these large protein molecules, although a decreased antibody formation in experimental animals exposed to lead has been reported.17

Despite the simplicity of techniques, polyacrylamide gel electrophoresis offered the possibility of separating the closely related constituents of plasma into discrete protein molecules. Figure 2 is a densitometric scan of the Coomassie-blue stained plasma polypeptides on a gel after electrophoresis in SDS. Several distinct components are observed. The main component is the albumin of molecular weight, about 68000 , which constitutes about $70 \%$ of the total plasma protein. ${ }^{18}$ Various globulin polypeptides known to have higher molecular weight (ranging from 80000 to 160000 ) appear before the albumin fraction.

Accompanying the electrophoretogram of plasma protein is the ${ }^{203} \mathrm{~Pb}$ radioactivity spectrum of the gel. Apparently lead is concentrated in the albumin fraction. No lead was found in the heavy molecular weight globulins. A trace amount of ${ }^{203} \mathrm{~Pb}$, however, was detected just before the albumin peak. This ${ }^{203} \mathrm{~Pb}$ association with gammaglobulin molecule is not surprising, as table 2 has shown that a small amount of lead was attached to the globulin fraction. Interestingly, Cember et al, ${ }^{19}$ who investigated the distribution of mercury in human plasma, found that a trace amount of mercury was first attached to the gammaglobulin and gradually transferred into albumin, which became the prominent binding fraction.

A confirmation experiment was performed on freshly prepared plasma. After ensuring that the
Table 3 Effect of enzymes on the binding of ${ }^{203} \mathrm{~Pb}$

\begin{tabular}{|c|c|c|}
\hline \multirow[t]{2}{*}{ Enzymes } & $\begin{array}{l}\text { nmol of Pb bound per } \\
\text { mg of membrane protein } \\
\text { Mean } \pm S E M\end{array}$ & \multirow[t]{2}{*}{$\begin{array}{l}\text { Decrease in bound } \\
{ }^{203} \mathrm{~Pb}(\% \text { untreated })\end{array}$} \\
\hline & Control & \\
\hline $\begin{array}{l}\text { Trypsin } \\
\text { Phospholipase }\end{array}$ & $178.3 \pm 17.692 .2 \pm 10.7$ & $48 \cdot 3 \pm 4 \cdot 7$ \\
\hline Neuraminidase & $\begin{array}{l}163.5 \pm 18.2138 .3 \pm 11.9 \\
152.3 \pm 16.4149 .5 \pm 15.5\end{array}$ & $\begin{array}{r}15.4 \pm 2.8 \\
1.8 \pm 0.2\end{array}$ \\
\hline
\end{tabular}

Mean radioactivity recovery was approximately $81 \%$.

plasma was haemoglobin free by scanning at $495 \mathrm{~nm}, 5 \mu \mathrm{Ci}$ of ${ }^{203} \mathrm{PbCl}_{2}$ was introduced. Electrophoresis was carried out in an identical manner. The results obtained were reproducible and essentially similar to that shown in fig 2 .

\section{EFFECTS OF ENZYMES ON ${ }^{203} \mathrm{~Pb}$ BINDING TO RBC MEMBRANE}

Table 3 shows the effects of commercially available enzymes on ${ }^{203} \mathrm{~Pb}$ binding in the erythrocyte membrane. All results are of three experiments, each in duplicate. Trypsin, which hydrolysed about $45 \%$ of the membrane protein, ${ }^{20}$ displaced about $50 \%$ of the bound ${ }^{203} \mathrm{~Pb}$. Phospholipase-C, which removed $69 \%$ of the phospholipid from the membrane, released only about $15 \%$ of the bound ${ }^{203} \mathrm{~Pb}$. Incubation of the membrane with neuraminidase for one hour at $60^{\circ} \mathrm{C}$, although cleaving $84 \%$ of the sialic acid residues from the membrane, had no significant effect on the ${ }^{203} \mathrm{~Pb}$ release.

Subsequent analysis of the supernatant by dialysis showed that most of the ${ }^{203} \mathrm{~Pb}$ in the soluble fraction was dialysable, suggesting that it did not have an affinity for the enzymes. The radioactivity recovered was $84 \%, 78 \%$, and $79 \%$ for trypsin, phospholipase$\mathrm{C}$, and neuraminidase, respectively.

Although the enzymes were not very specific in their action on the membrane, trypsin also released $23 \%$ of the phospholipid and $61 \%$ of the sialic acid during hydrolysis, and phospholipase- $\mathrm{C}$ released about $16 \%$ of the membrane protein. These results are compatible with the suggestion that most of the firmly bound ${ }^{203} \mathrm{~Pb}$ is associated with membrane protein and to a lesser extent with phospholipid; sialic acid may play only a minor part in the binding of ${ }^{203} \mathrm{~Pb}$.

\section{STUDY OF GROUPS ASSOCIATED WITH} LEAD BINDING

Ong and Lee ${ }^{11}$ present evidence that carboxyl groups are responsible for the binding of about $68 \%$ of ${ }^{203} \mathrm{~Pb}$ in the erythrocyte membrane and the thiol $(\mathrm{SH})$ groups for about $18 \%$. The amino groups did not appear to bind a significant amount of ${ }^{203} \mathrm{~Pb}$. 


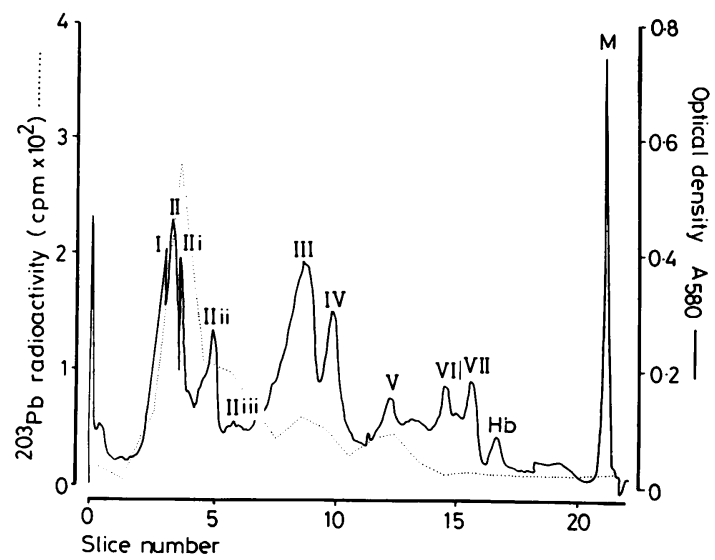

Fig 3 Distribution of ${ }^{203} \mathrm{~Pb}$ in the erythrocyte membrane.

DISTRIBUTION OF ${ }^{203} \mathrm{~Pb}$ IN THE ERYTHROCYTE MEMBRANE

The erythrocyte membrane has been shown to carry about $14 \%$ of blood lead (fig 1). Attempts were made to define more closely the principal binding groups in the stromal membrane by electrophoresis.

The erythrocyte membranes were prepared as described in the methods section. The membrane (ghosts) pellet was then washed three times to remove the cations loosely associated with the membrane, leaving those ${ }^{203} \mathrm{~Pb}$ ions that were firmly bound. The labelled stromal membranes were then dissolved in an excess of SDS, and the polypeptides were denatured and separated in polyacrylamide gel according to the methods of Fairbanks et al. ${ }^{14}$

Figure 3 shows the densitometric scan of Coomassie-blue stained ghosts polypeptide after electrophoresis in SDS. The protein profile consists

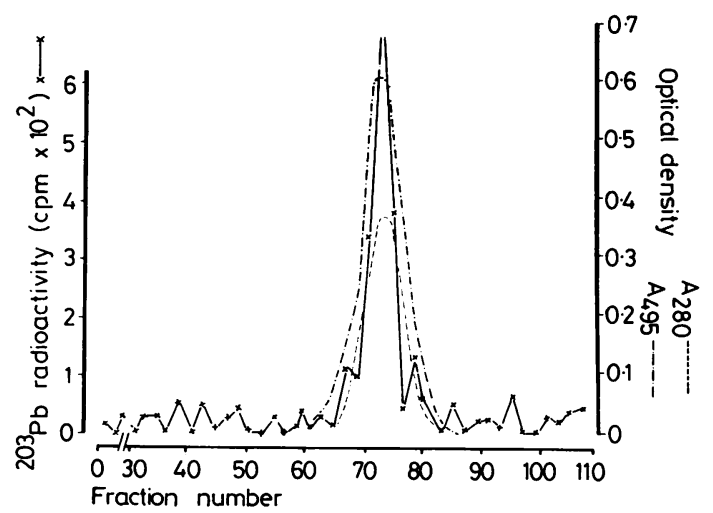

Fig 4 Sephadex G-75 chromatography of haemolysate. of several well-resolved bands and is arbitrarily labelled I-VII according to Steck. ${ }^{21}$ The configuration of these protein groups is molecular weight dependent and is in descending order from left to right.

The ${ }^{203} \mathrm{~Pb}$ distribution shows two notable features:

(1) The prominent radioactivity peak was apparently associated with high molecular weight polypeptide II and its subordinate components. These polypeptides are known to have a molecular weight of about 130000 to 230000 .

(2) Trace amounts of radioactive lead were recovered in polypeptides III and IV. There was also some in polypeptide $\mathrm{V}$.

\section{ASSOCIATION OF LEAD WITH}

INTRACELLULAR CONSTITUENT

Figure 4 is the chromatogram of haemolysate separated by G-75 and shows $(a)$ the elution characteristics of the protein band with the calibrated graph suggest a mean molecular weight of 67000 , which is virtually that of haemoglobin polypeptide, and $(b)$ the radioactive peak together with the protein and haemoglobin all appeared on the same fractions (fraction 68 to 73 ).

The radioactive labelled material lost in the chromatography column is only a small amount $(8 \%)$ in comparison to the binding in the protein fraction; it is reasonable therefore to conclude that haemoglobin is the principal molecule interacting with the ${ }^{203} \mathrm{~Pb}$.

A similar result was obtained with haemolysate, which had been in direct contact with ${ }^{203} \mathrm{~Pb}$ in vitro for 60 minutes, suggesting that the organised red cell plays little part in determining binding site and that the initial binding is probably of a chemical or physical type rather than through a complex of biological sequences.

\section{Discussion}

This study was designed to investigate the distribution of lead in human peripheral blood, and to identify possible lead binding sites. Peripheral blood is the first tissue after absorption to receive lead absorbed either from the gastrointestinal tract or respiratory system en route to other organs. ${ }^{22}$ The actual kinetics of lead distribution are complicated, but it is generally presumed to be transported by the blood. ${ }^{12}$

The high proportion of ${ }^{203} \mathrm{~Pb}$ found in the erythrocytes confirms the in-vitro findings reported by Clarkson and Kench ${ }^{4}$ and the limited uptake of lead by the plasma is in accordance with the in-vivo observations of Baloh. ${ }^{23}$ 
Very little is known about lead in plasma. It has been suggested that it comprises two fractions, a diffusible metabolically active fraction and a complex protein bound fraction. ${ }^{24}$ Gurd and Murray, ${ }^{25}$ however, showed that virtually all the lead in the plasma was associated with the protein fraction. The present study using electrophoresis suggests that ${ }^{203} \mathrm{~Pb}$ is bound to plasma albumin and only a trace fraction is associated with high molecular weight globulins. There is no evidence from the present observations whether the minor fraction associated with the globulins is an active fraction, and that with albumin is a stable protein complex.

The distribution of ${ }^{203} \mathrm{~Pb}$ in erythrocyte membranes (fig 3) suggested that the binding of this metal at the membrane is heterogeneous and included many groups. According to Steck, ${ }^{21}$ polypeptide II is a large molecule and is adherent to the inner surface of the red cell membrane. This polypeptide is known to have a molecular size of about 130000 to 230000 .

Although the bindings of ${ }^{203} \mathrm{~Pb}$ to polypeptides III and IV are less than that to polypeptide II, various sources available have suggested that the polypeptide band III might be concerned in the interaction with lead. This polypeptide has a molecular weight of about 82000 to 85000 and represents about $20 \%$ of the total membrane protein ${ }^{26}$ and is known to have a high content of protein sulphydryl (SH) groups. ${ }^{27}$ Therefore the binding of ${ }^{203} \mathrm{~Pb}$ to this band is not surprising, as lead has been shown to react with sulphydryl groups. Furthermore, it has been suggested that this polypeptide spans and penetrates the membrane, and thus may participate in ion transportation. ${ }^{21}$ Recently, this polypeptide was reported to contain a phosphorylated intermediate of $\mathrm{Na}^{+} / \mathrm{K}^{+}$-ATPase. ${ }^{28}$ If this is the case it may in part explain the mechanism by which lead inhibits $\mathrm{Na}^{+} / \mathrm{K}^{+}$-stimulated adenosine triphosphatase. ${ }^{29} 30$

In the present investigation membrane proteins were separated by polyacrylamide gel electrophoresis, and the results suggested that ${ }^{203} \mathrm{~Pb}$ is attached to high molecular weight polypeptides (MWt 130000 230000 ). This finding confirms our earlier observation, when erythrocyte membrane proteins were separated by gel chromatography.11

Use of group specific reagents suggested that the binding of ${ }^{203} \mathrm{~Pb}$ in red blood cell membrane is heterogeneous and that the binding sites are multiple. Carboxyl groups have been shown ${ }^{11}$ to be those that interact most with the lead. This observation may be compared with that of Duffy and Schwarz, ${ }^{13}$ who showed that carboxyl groups are concerned in the formation of the intermediate of $\mathrm{Na}^{+} / \mathrm{K}^{+}$-ATPase. If lead combines with the carboxyl group at the active site of $\mathrm{Na}^{+} / \mathrm{K}^{+}$-ATPase the phosphorylation activity of the enzymes would be prevented, as noted above. Other groups may also be concerned in ${ }^{203} \mathrm{~Pb}$ binding; inhibition of the membrane $\mathrm{SH}$ groups with PCMB has suggested that sulphydryl groups may have a minor role.

Examination of blood components at the molecular level indicated that lead has a strong affinity for plasma and erythrocyte protein (table 2). Only an insignificant amount of ${ }^{203} \mathrm{~Pb}$ was recovered from the lipid fraction and less than $6 \%$ was in free ionic form. These results confirmed our other findings ${ }^{11}$ and are markedly consistent with in-vivo results reported by Beattie et al. . $^{31}$

The distribution of ${ }^{203} \mathrm{~Pb}$ in erythrocytes helps to explain the long controversy of lead binding at the stromal membrane 410 and at the cytoplasm. ${ }^{78}$ These groups of investigators did not apparently differentiate these two constituents. The present investigation shows that erythrocyte haemolysate has a strong affinity for ${ }^{203} \mathrm{~Pb}$. This confirms the result of Bruenger et $a l^{32}$ who showed that $210 \mathrm{~Pb}$ interacted with an intracellular constituent and only a small amount is attached to the membrane of red blood cells.

We thank the Medical Research Council Cyclotron Unit for supplying the radioisotope ${ }^{203} \mathrm{~Pb}$. We are also very indebted to $\mathrm{Mr} \mathrm{C} \mathrm{J}$ Whitaker not only for statistical help but also for his help in preparing this paper.

This work formed part of a thesis submitted to the University of Manchester for the degree of PhD by C N Ong.

\section{References}

${ }^{1}$ Barltrop D. Environmental lead and its significance. Postgrad Med J 1969;45:129-35.

${ }^{2}$ Booker DV, Chamberlain AC, Newton DA, Stott A. Uptake of radioactive lead following inhalation and injection. Br J Radiol 1969;42:457-62.

${ }^{3}$ Mortensen RA, Kellog KE. The uptake of lead by blood cells as measured with a radioactive isotope. $J$ Cell Physiol 1944;23:11-6.

4 Clarkson TW, Kench JE. Uptake of lead by human erythrocytes in vitro. Biochem $J$ 1958;69:432-4.

${ }^{5}$ Passow H, Rothstein A, Clarkson TW. The general pharmacology of heavy metals. Pharmacol Rev $1961 ; 13$ : 185-205.

- Reddi KK. Isolation of thorium-B (lead) -binding substances from erythrocytes of rabbit blood. Nature 1953; 172:202.

${ }^{7}$ Barltrop D, Smith A. Interaction of lead with erythrocytes. Experientia $1971 ; 27: 92-3$.

${ }^{8}$ Barltrop D, Smith A. Lead binding to human haemoglobin. Experientia 1972;28:76-8.

9 White JM. Lead and the red cell. Br J Haematol 1975; 30:133-6.

${ }^{10}$ Selhi HS, White JM. The effect of lead on red cell membrane. Postgrad Med J 1975;51:765-8.

11 Ong CN, Lee WR. Interaction of calcium and lead in human erythrocytes. Br J Ind Med 1980;37:70-7. 
12 Tombs MP, Akroyd P. Acrylamide gei electrophoresis. Shandon Instrument Applications No 18. London: Pitman Medical Scientific, 1967.

${ }^{13}$ Duffy MJ, Schwarz V. Molecular groups responsible for the binding of calcium ions in the erythrocyte membrane. Biochem Soc Trans 1974;2:403-4.

14 Fairbanks G, Steck TL, Wallach DFH. Electrophoretic analysis of the major polypeptides of the human erythrocyte membrane. Biochemistry 1971 ;10:2606-15.

${ }^{15}$ Takeda Y, Kunudi T, Hoshino O, Ukita T. Distribution of inorganic alkyl mercury compounds in rats. Toxicol Appl Pharmacol 1968;13:156-62.

16 Turner NW, Hulme B. The plasma proteins; an introduction. London: Pitman Medical Scientific, 1971.

${ }^{17}$ Koller LD, Kovacic S. Decreased antibody formation in mice exposed to lead. Nature $1974 ; 250: 148$.

${ }^{18} \mathrm{Killander} \mathrm{J}$. Separation of human heme and Hb-binding plasma proteins. Biochem Biophys Acta 1964;93:1-12.

19 Cember H, Gallagher P, Faulkner A. Distribution of $\mathrm{Hg}$ among blood fractions and serum proteins. Am Ind Hyg Assoc 1968;29:233-8.

${ }^{20}$ Duffy M. PhD Thesis. University of Manchester, 1974.

21 Steck TL. The organisation of proteins in the human red blood cell membrane. J Cell Biol 1974;62:1-21.

${ }^{22}$ Rabinowitz M, Wetherill GW, Kopple JD. Studies of human lead metabolism by use of stable isotope tracers. Environ Health Perspect 1974;7:145-51.
${ }^{23}$ Baloh RW. Laboratory diagnosis of increased lead absorption. Arch Environ Health 1974;28:198-208.

${ }^{24}$ Goyer RA. Lead toxicity-A problem in environmental pathology. Am J Pathol 1971;64:176-82.

${ }^{25}$ Gurd FRN, Murray JR. Preparation and properties of serum and plasma proteins. J Am Chem Soc 1954;76: 187-91.

26 Wallach DFH. The plasma membrane. London: English Universities Press Ltd, 1973.

${ }^{27}$ Brown PA, Feinstein MB, Shaffi RI. Membrane proteins related to water transport in human erythrocytes. Nature 1975;254:523-4.

${ }^{28}$ Avruch J, Fairbanks C. Demonstration of a phosphopeptide intermediate in the $\mathrm{Mg}^{++}$-dependent $\mathrm{Na}^{+}-\mathrm{K}^{+}$ stimulated ATPase reaction of the erythrocyte mem:brane. Proc Nati Acad Sci USA 1972;69:1216.

29 Hasan J, Vihko V, Hernberg S. Deficient red cell membrane $\mathrm{Na}^{+}-\mathrm{K}^{+}$ATPase in lead poisoning. Arch Environ Health 1967;14:313-7.

${ }^{30}$ Secchi GC, Alessio L, Cambiaghi G. $\mathrm{Na}^{+} / \mathrm{K}^{+}$ATPase activity of erythrocyte membranes. Arch Environ Health 1973;27:399-404.

${ }^{31}$ Beattie AD, Moore MR, Goldberg A. Tetraethyl-lead poisoning. Lancet $1972 ; 2: 12-5$.

${ }^{32}$ Bruenger FW, Stevens W, Stover BJ. The association of ${ }^{210} \mathrm{~Pb}$ with constituents of erythrocytes. Health Phys $1973 ; 25: 37-42$. 